\title{
Local elections and community health care in Nepal
}

\author{
Pramod R. Regmi ${ }^{1-3^{*}}$, Edwin van Teijlingen ${ }^{1,4-6}$, Padam Simkhada ${ }^{5-7}$, Nirmal Aryal ${ }^{8}$ \\ ${ }^{1}$ Faculty of Health and Social Sciences, Bournemouth University ${ }^{2}$ Chitwan Medical College, Tribhuvan University, Nepal ${ }^{3}$ Datta Meghe Institute of Medical Sciences, \\ India ${ }^{4}$ School of Health Sciences, University of Nottingham, UK ${ }^{5}$ Manmohan Memorial Institute of Health Sciences, Tribhuvan University, Nepal ${ }^{6}$ Nobel College, \\ Pokhara University, Nepal ${ }^{7}$ Centre for Public Health, Liverpool John Moores University, UK ${ }^{8}$ University of Otago, New Zealand
}

\section{Received: \\ 27 July 2017}

\section{Revised:}

6 November 2017

\section{Accepted:}

7 November 2017

\section{${ }^{\star}$ Correspondence: pregmi@bournemouth. ac.uk \\ Faculty of Health and Social Sciences, Bournemouth University, England, UK}

Health News about elections being postponed, delayed, rigged or their results ignored are common in some of the countries low on the international corruption index (1), but it is slightly odd to see a country with regular national elections denying this democratic right at a local level. Nepal has been a parliamentary democracy since 1991 with regular national elections. After a Maoist rebellion, and the subsequent popular People's Movement of 2006, the new secular democratic republic state was enshrined in the 2015 constitution. This has not only brought the peace process to a logical conclusion with a federal constitution that reshaped the governance structure, it has also ensured fundamental civic, social and economic rights. For example, the several articles such as Articles 17, 18, 28, 30, 35, 38-40, 42, 51 of the constitution cover health-related issues from the perspective of 'fundamental rights' to individuals (2).

At a local level public bodies were last elected in 1997. Their five-year term of office was completed in 2002, at the height of the conflict between the government and the Maoists. Subsequent Governments were not able to hold local elections due to their incapacity to maintain peace and security and elected representatives were therefore replaced by government officials. Perhaps because of absence of people representatives in local bodies corruption flourished, hampering the delivery of health service in local communities. During this political conundrum, there was an attempt to form an all-party representative committee in local bodies but was ineffective in reality. Indeed, this long gap between local elections had left an institutional vacuum at the local level, obstructing the smooth delivery of basic health and social care services. This was also clearly mirrored in the performance to recovery from 2015 earthquake which killed more than 9000 people and destroyed hundreds of primary health care infractures (3).

The current 2017 local election was being held for the first time in two decades with differentprovinces going to the polls in different stages. This is a landmark moment in the country's transition to democracy. The outcomes of this election are important to strengthen the local health system as well as infrastructures because it increases accountability of local service providers, who will now be overseen by elected representatives in the community, in the long run this will hopefully enhance good governance and reduce corruption. Furthermore, the Ministry of Federal Affairs and Local Development (4) has recently circulated directives around roles and responsibilities of local bodies. They include several health-related programmes and advocacy such as implementing public health awareness, provision of urban health clinics, managing health care centres, managing programmes such as vaccinations and vitamins to children, provision of safe drinking water, and management of waste, and clean environment in the communities. Socio-economic empowerment is also the heart of the directives, aiming to end inequalities, discrimination, girls trafficking, and child labour in their community.

Despite the decade-long political transitions, Nepal has made significant progress on achieving the millennium development goals (MDGs) and has been globally recognised for the impressive outcomes (5-6). However, there are wide variations in health services availability, utilisation and health status across different socio-economic and geographical population groups, indicating the challenge of access and equity. For instance, the recently published Annual Report 2014/2015 by the Ministry of Health documents that whilst some districts have 100\% position of medical doctors filled, of the 32 sanctioned posts in Saptari district, only 5 (16\%) are filled (7). Similarly, the Nepal Demographic Health Survey 2016 reveals that the unmet need for family planning is highest in Province 4 (30\%) and lowest in State 3 (20\%). The proportion of women receiving ANC from a skilled provider also varies from $73 \%$ in Province 6 to $91 \%$ in Province 7. Children in Province 2 are least likely to receive vitamin A supplements (8). To reduce this inequality, together with relevant stakeholders and service users group, the local level leaders should formulate health promotion and health care programmes that are locally and culturally appropriate. Sustainability and local ownership of these programmes should be carefully thought therefore need assessment through a participatory approach in the local level is the first step to move this forward. The local leaders should also strengthen the vital registration system (VRS) in the community as the data generated from this source is not adequate to have a well-functioning health systems in Nepal.

Being a signatory country of the Sustainable Development declaration, Nepal should turn the vision of the Sustainable Development Goals (9) into reality. The newly elected and aspiring local leaders have a 
window of opportunity: priortizing the health needs relevant to local context, improving provision and access to health care at local level, reducing health inequalities in an otherwise excellent health system should now be their priority along with infrastructure development. Elected local governments are critical for public accountability on the operationalization of the SDGs at the local levels and to properly address the issues of targeted people. Having elected leaders in communities after such a long gap will certainly give Nepalese people rights and hopefully improve provision and access to health care services they are entitled to. We have a notion that the role of civil society, community based non-governmental organisation, development partners and the mass-media is critical for advocacy for effective monitoring and implementation of activities at local level. The Ministry of Health has also recently charted out the "Integrated Health Infrastructure Development Plan" which envisaged enhancing availability and access to quality health services in Federal Nepal (10). With these delayed but promising political developments, we believe that health care system in Nepal is heading towards the significant improvement.

\section{Conflict of Interests}

The authors declare that they have no competing interests.

\section{References}

1. Transparency International. 2016. Corruption Perceptions Index 2016. Available: https://www.transparency.org/news/feature/corruption_perceptions_index_2016 [Accessed July 3 2017]

2. Constitutional Assembly Secretariat. 2015. Constitution of Nepal 2015. Kathmandu, Nepal: Constitutional Assembly Secretariat.

3. Regmi, P.R., Aryal, N., Pant, P.R., van Teijlingen, E., Simkhada, P. and Devkota, B., 2015. Priority public health interventions and research agendas in postearthquake Nepal. South East Asia Journal of Public Health, 5(2),7-12.

4. Ministry of Federal Affairs and Local Development. 2017. Local Level Governing Ordinance 2016. Available: http://www.mofald.gov.np/en/node/1829 [Accessed July 2 2017]

5. Regmi, P., van Teijlingen, E., Hundley, V., Simkhada, P., Sharma, S. and Mahato, P.K., 2016. Sustainable Development Goals: relevance to maternal and child health in Nepal. Health Prospect: Journal of Public Health, 15(1), 9-10.

6. Nepal Planning Commission. 2016. Nepal and the Millennium Development Goals Final Status Report 2000-2015. Available: http://www.npc.gov.np/images/ category/MDG-Status-Report-2016_.pdf [Accessed July 3 2017]

7. Department of Health Services. 2017. Annual Report 2014/15. Available: http://dohs.gov.np/wp-content/uploads/2016/06/Annual_Report_FY_2071_72.pdf [Accessed July 12017 ]

8. Ministry of Health, Nepal, New ERA, and ICF. 2017. Nepal Demographic and Health Survey 2016: Key Indicators. Kathmandu, Nepal: Ministry of Health, Nepal Available: https://dhsprogram.com/pubs/pdf/PR88/PR88.pdf [Accessed July 1 2017]

9. United Nations. 2015. Transforming our world: The 2030 agenda for sustainable development. New York: United Nations. Available: https://sustainabledevelopment. un.org/post2015/transformingourworld [Accessed June 12 2017]

10. What are the changes in the existing health care system in Federal Nepal? Available: https://www.phpnepal.org.np/publication/current-issue/national-news/139what-are-the-changes-in-the-existing-health-care-system-in-federal-nepal [Accessed June 20 2017] 